\title{
"IN VITRO" EVALUATION OF THE APICAL SEALING OF ROOT CANALS OBTURATED WITH DIFFERENT TECHNIQUES
}

\author{
AVALIAÇÃO “IN VITRO” DO SELAMENTO APICAL DOS CANAIS \\ RADICULARES EM FUNÇÃO DE DIFERENTES TÉCNICAS DE OBTURAÇÃO
}

\author{
Viviane Haiub BROSCO \\ DDS, MSc Graduate student, Department of Endodontics, Bauru Dental School, USP. \\ Norberti BERNARDINELI \\ DDS, MSc PhD, Assistant Professor, Department of Endodontics, Bauru Dental School, USP. \\ Ivaldo Gomes de MORAES \\ DDS, MSC, PhD Associate Professor, Department of Endodontics, Bauru Dental School, USP.
}

\begin{abstract}
7 he purpose of this study was to compare the apical sealing of root canals obturated with different techniques. One hundred-six human mandibular incisors were submitted to instrumentation by means of the step-back technique. After instrumentation, one hundred teeth received an impermeable coating on the external surfaces of the crown and root (except for the area nearby the apical foramen). Afterwards, they were divided in five groups containing twenty elements each, according to the obturation technique employed: 1 . lateral condensation with Kerr file; 2. continuous wave of condensation technique with System B; 3. thermoplasticized injectable guttapercha technique with the Ultrafil system; 4. mechanically thermoplasticized gutta-percha with the JS Quick-Fill system and 5. thermoplasticized gutta-percha associated to a master cone with the Microseal system. The six remaining teeth were employed as negative and positive controls. After obturation, the access cavities were sealed and the teeth were immersed in aqueous $2 \%$ methylene blue dye for 72 hours at $37^{\circ} \mathrm{C}$. After that, the teeth were longitudinally sectioned and the apical microleakage was evaluated in a stereomicroscope. The Microseal system presented the best apical sealing ability, followed by System B, JS Quick-Fill, Ultrafil and the lateral condensation technique. The statistical analysis of the results demonstrated that: 1. the Microseal system presented an apical sealing similar to System B and better than the other groups; 2. System B presented better apical sealing than the lateral condensation technique, being similar to the other groups; and 3. the lateral condensation, Ultrafil and JS Quick-Fill groups demonstrated similar sealing ability.
\end{abstract}

UNITERMS: Root canal obturation; Dental leakage.

\section{INTRODUCTION}

The complete obturation of the root canal system and the creation of a fluid-tight have been proposed as goals for successful endodontic treatment ${ }^{16}$.

It has been determined that approximately $60 \%$ of endodontic failures are due to inadequate obturation of the root canal system ${ }^{11}$. Such failures have been attributed to penetration of substances from the apical tissues into the canal. Additionally, failure could be caused by irritants left in the canal that may seep out through an inadequate seal into the periapical tissues ${ }^{13}$.

Cold Lateral Condensation of gutta-percha is currently the most popular obturation technique ${ }^{14}$; however, some authors ${ }^{8,16}$ have reported that Lateral Condensation does not result in a homogenous mass of gutta-percha.

Many different filling techniques based on warmgutta-percha have been introduced and investigated in order to identify the one that would provide the best sealing of the canal ${ }^{14}$.

The continuous wave of condensation technique has been introduced and has been reported to simplify and speed up vertical condensation of the root canal system. The technique uses a new device, the System 
$\mathrm{B}$, which can be heated to a preset temperature prior to vertically condensing the gutta-percha within the root canal ${ }^{4,7,15}$.

The Ultrafil system is based on the technique of low-temperature $\left(70^{\circ} \mathrm{C}\right)$ injection of thermoplasticized gutta-percha. The cannula that contains gutta-percha is preheated and inserted into the root canal with injection syringe ${ }^{1,6}$.

The JS Quick-Fill is a root canal obturation system in which a titanium carrier covered with gutta-percha is warmed by wall friction by rotating it within the root canal ${ }^{5,10,17}$

The Microseal endodontic obturation system, associates a master gutta-percha cone with thermoplasticized gutta-percha, which is inserted into the root canal with a compactor ${ }^{2,12}$.

The purpose of the study was to compare the apical sealing quality obtained with different root canal obturation techniques.

\section{MATERIAL AND METHODS}

A total of 106 human mandibular incisors of similar size, with single and straight canals, were used in this study. After extraction, all teeth were stored in $10 \%$ formalin. Six teeth served as controls, 3 positive and 3 negative ones, and 100 were used in the experimental groups. Teeth were cleaned with periodontal curettes to remove any calculus or soft tissue debris and were subsequently stored in saline solution throughout the experimental period.

Lingual access cavities were prepared with round diamond burns in a high-speed water-cooled handpiece.

The root canals were prepared by the same operator using K-files (Maillefer Instruments, Ballaigues, Switzerland). A 15 file was introduced into the canal until it could be seen in the apical foramen. The canals were instrumented to a 25 file in this length for standardization of the diameter of the apical foramen. The working length was established as $1 \mathrm{~mm}$ short of the apex. The canals were instrumented with K-files to size 40 in this length in order to create an apical stop. The rest of the canal was flared to a size 60 file with circumferential filing action using a step-back technique ${ }^{18}$.

Normal saline was used for irrigation throughout the instrumentation process.

After instrumentation, the patency of the apical foramen was confirmed with a $25 \mathrm{~K}$-file and the canals were irrigated with 17\% EDTA (Odahcam Dentsply Ind. Com. LTDA, Brazil) to remove the smear layer, followed by a final rinse with saline solution.

The experimental and positive control teeth were coated with one layer of araldite (Brascola LTDA, Brazil) and two layers of nail polish (Risqué, Niasi S.A., Brazil), except for the apical $1 \mathrm{~mm}$ that was left exposed so that the tracer could only penetrate the canal via the apical region. The negative control teeth were fully coated, including the apical region. The teeth were then stored in saline solution. Prior obturation, the root canals were dried with paper points.

The positive and negative control teeth were not obturated.

The 100 teeth were divided into 5 experimental groups of 20 teeth each. Endofill (Dentsply Ind. Com. LTDA, Brazil) was used as sealer, mixed according to the manufacture's instruction and then applied to the canal of all teeth with a $40 \mathrm{~K}$-file. Next, the root canals were obturated according to the following techniques:

Group 1 - Lateral Condensation: a size 40 guttapercha master cone (Tanariman Ind. LTDA, Brazil) was fitted with tugback at the working length. Lateral Condensation was performed with a $30 \mathrm{k}$-file, used as a spreader ${ }^{3}$ and B7 acessory gutta-percha points (Tanariman Ind. LTDA, Brazil). Condensation was completed when the spreader could not penetrate beyond 3 to $4 \mathrm{~mm}$ from the orifice.

Group 2 - System B - (Analytic Endodontics, Sybron Endo, USA) used according to the manufacturer's instruction. A size fine-medium nonstandardized master gutta-percha cone was selected and cut at its apical third to the size of master apical file preparation. The "tugback" was confirmed in the working length and the master cone was seated in the root canal. Downpack - The fine-medium System B plugger was selected and marked at its binding point with a rubber stopper, $5 \mathrm{~mm}$ short of the working length. System B was adjusted at $200^{\circ} \mathrm{C}$, power setting 10. and the touch mode. The preheated plugger was driven through the gutta-percha to approximately 3 $\mathrm{mm}$ short of the binding point. While maintaining compaction pressure, the touch switch was released, as the plugger was moving downwards for placement stopping just of the binding point. A firm apical pressure was maintained for about $10 \mathrm{~s}$, allowing the apical segment of gutta-percha to cool under this force to counter shrinkage of gutta-percha. Additional heat was then applied for 1s whilst the plugger was held in position for 1 more $\mathrm{s}$. The plugger was then removed. Backfilling - a size fine-medium non-standardized master gutta-percha cone was selected and trimmed until "tugback" was achieved. The System B plugger was adjusted at $100^{\circ} \mathrm{C}$, activated for $0.5 \mathrm{~s}$ and placed 
to half its previous depth in the canal. The System B plugger was rotated and removed. The second backfill cone was introduced into the void by the plugger. The temperature setting was increased to $200^{\circ} \mathrm{C}$, the coronal gutta-percha heated for $2 \mathrm{~s}$ and condensed using a hand plugger.

Group 3 - Ultrafil (Hygenic, Coltène/Waledent Inc., USA) used according to the manufacturer's instructions. The firm set gutta-percha cannula was warmed inside the heater for $3 \mathrm{~min}$ and inserted into the injection syringe. The flow of the gutta-percha cannula was confirmed and the needle wiped clean. The needle was inserted into the canal to a level of 6 $\mathrm{mm}$ short working length and the thermoplasticized gutta-percha was injected to obturate the apical third. When backpressure was felt, the needle was slowly withdrawn from the canal and the thermoplasticized gutta-percha was injected into the other thirds of the canal.

Group 4 - JS Quick-Fill - (JS Dental Manufacturing, Inc., USA) used according to the manufacturer's instructions. A size 30 JS Quick-Fill (two sizes smaller than the last file used to prepare the apical third of the canal) was selected. The rubber stop was inserted into the carrier at the correct length and the carrier was placed in the canal in a conventional slow-speed handpiece until a slight resistance was noted. Clockwise rotation at $6000 \mathrm{rpm}$ was started and when gutta-percha plasticity was noted the carrier was slowly advanced until reaching working length. The core of the JS Quick-Fill was then removed from the canal with pressure applied to one side of the canal while continuing clockwise rotation.

Group 5 - Microseal - (Analytic Endodontics, Sybron Endo, USA) used according to the manufacturer's instructions. For all teeth, a size 40 and taper 0.02 master gutta-percha cone was selected and "tugback" was confirmed in the working length. The master gutta-percha cone was seated in the root canal. The $30 \mathrm{k}$-file used as a spreader was inserted alongside the master cone $3 \mathrm{~mm}$ short of the working length and withdrawn, creating a tapered void between the compacted gutta-percha cone and the root canal walls. The size 45 and taper 0.04 mechanical compactor was inserted into the heated gutta-percha cartridge and coated with a uniform layer of material. The gutta-percha coated compactor was then immediately carried to the void previously created in the canal by the spreader and was placed $3 \mathrm{~mm}$ short of the working length, avoiding rotation as it was inserted. With the application of a resisting force to the compactor's backing-out motion, but without any apical pressure, rotation of the compactor was started at a speed of $6000 \mathrm{rpm}$. After $2 \mathrm{~s}$, the compactor was removed slowly, whilst being softly pushed against one side of the canal. Rotation did not stop until the compactor was removed fully from the canal. The spreader was re-inserted into the center of the guttapercha filling. More gutta-percha was placed on the compactor and deposited into the canal.

In all experimental groups, after canal obturation, the coronal gutta-percha was compacted vertically using a hand plugger. The access cavities were closed with cimpat (Septodont DFL, Spain) and coated with a layer of sticky wax.

Subsequently, all the teeth were immersed in aqueous $2 \%$ methylene blue dye, $\mathrm{pH} 7$, at $37^{\circ} \mathrm{C}$ for 72 hours. After this time, the teeth were removed from the dye and washed in running water, and nail polish was removed with a curette.

A longitudinal groove from the coronal to the apical aspect was cut into the labial and lingual surfaces of each root; the roots were then split with a chisel.

Linear dye penetration was measured along the canal filling interface, from the most apical extent of gutta-percha to the most coronal point of dye penetration. The measurements were made by two different examiners using a stereomicroscope (Bausch \& Lomb - USA) at 4x magnification and a calibrated scale eyepiece.

Data were analyzed statistically by the KruskalWallis test and the Dunn test. The level of significance was set at $p<0.05$.

\section{RESULTS}

The positive controls showed dye penetration into the canals and dentinal tubules of the teeth, whereas the negative controls did not demonstrate dye penetration, indicating that the leakage model chosen was appropriate for the purpose of the present study.

The apical linear dye penetration of the experimental groups (mean $+\mathrm{SD}$ ) is summarized in Table 1 .

In the experimental groups, obturation with the Microseal system showed the lowest dye penetration $(0.47 \mathrm{~mm})$, followed by System B $(0.82 \mathrm{~mm})$, JS QuickFill $(2.34 \mathrm{~mm})$, Ultrafil $(2.42 \mathrm{~mm})$ and the Lateral Condensation technique, which showed the greatest dye penetration $(2.81 \mathrm{~mm})$.

The analysis of the results demonstrated that was no statistically significant difference between the Lateral Condensation, Ultrafil and JS Quick-Fill groups.

A statistically significant difference was detected between the Microseal system and the Lateral Condensation, Ultrafil and JS Quick-Fill groups. There 
was no statistically significant difference between the Microseal system and System B.

A statistically significant difference was detected between System B and Lateral Condensation, whereas no significant difference was observed between System $\mathrm{B}$ and the other groups.

\section{DISCUSSION}

The literature shows wide diversification with respect to the apical infiltration caused by the Lateral Condensation technique. In the present study, this technique presented a higher mean apical infiltration compared to the remaining techniques, as also reported by others ${ }^{2,15}$. Lateral Condensation produces a less homogeneous obturation with poorer adaptation to the canal walls compared the techniques that use thermoplasticized gutta-percha ${ }^{8,16}$. This may possibly explain the fact that the root canals obturated with this technique numerically presented the highest mean apical infiltration.

The Microseal system presented the lowest mean apical infiltration, followed by System B, with no significant difference between them. These data agree with those reported by Davalou, Gutmann, Nunn ${ }^{7}$ in 1999, who observed that all specimens obturated with the Microseal system presented infiltration of less than $1 \mathrm{~mm}$ and that only one tooth obturated with System B presented apical infiltration of more than $1 \mathrm{~mm}$.

Microseal and System B presented a significantly better sealing ability than Lateral Condensation, as also reported by others ${ }^{2,15}$. The better sealing provided by Microseal may be attributed to the technique used and to the good physical properties of the gutta-percha of this system such as high adhesiveness, low melting temperature and the molding ability of the apical stop when gutta-percha is plasticized ${ }^{2,12}$.

The Ultrafil system showed apical sealing similar to that of JS Quick-Fill and of the Lateral Condensation technique. Greene, Wong, Ingram ${ }^{9}$, in 1990 also did not detect a statistically significant difference between the Ultrafil system and the Lateral Condensation technique, whereas Gençoglu, Samani, Günday ${ }^{8}$ in 1993 demonstrated that the Ultrafil system produces homogeneous obturations with excellent adaptation to the irregularities of the canal.

The present results demonstrate that there was no statistically significant difference between the JS QuickFill system and the Lateral Condensation technique, a result also reported by Pallares, Faus ${ }^{14}$ in 1995. However, during obturation with the JS Quick-Fill system gutta-percha did not present adequate plastification, generating doubts about the quality of obturation and about whether the amount of guttapercha that remains after removal of the root canal compactor is sufficient to promote three-dimensional obturation, especially in wide canals.

Since these obturation systems are recent, further research is necessary for a better evaluation of their characteristics and for improvement of obturation techniques in view of the importance of the latter for successful treatment of root canals.

\section{CONCLUSIONS}

1- The Microseal system presented an apical sealing similar to System B and better than the other groups

2- System B presented better apical sealing than the Lateral Condensation technique, being similar to the other groups.

3- The Lateral Condensation, Ultrafil and JS QuickFill groups demonstrated similar sealing ability.

\section{RESUMO}

Este estudo teve como objetivo avaliar o selamento apical de canais radiculares obturados por diferentes técnicas. Cento e seis incisivos inferiores humanos tiveram seus canais instrumentados através da técnica escalonada regressiva. Após a instrumentação, cem

TABLE 1- Mean apical leakage and standard deviation for the experimental groups

\begin{tabular}{lcc}
\hline Groups & Mean leakage $(\mathbf{m m})$ & Standard deviation \\
\hline Lateral Condensation & 2.81 & 1.82 \\
System B & 0.82 & 0.73 \\
Ultrafil & 2.42 & 2.36 \\
JS Quick-Fill & 2.34 & 2.30 \\
Microseal & 0.47 & 0.46
\end{tabular}


dentes foram impermeabilizados, exceto nas proximidades do forame apical, e divididos em cinco grupos de vinte elementos cada, de acordo com a técnica de obturação utilizada: 1 . condensação lateral ativa realizada com lima tipo Kerr; 2 . Onda Contínua de Condensação realizada com o System B; 3. guta-percha termoplastificada injetável realizada com o sistema Ultrafil; 4. guta-percha termoplastificada mecanicamente realizada com o sistema JS Quick-Fill; 5. guta-percha termoplastificada associada a um cone principal realizada com o sistema Microseal. Os seis dentes restantes foram utilizados como controles positivo e negativo. Após a obturação, os dentes foram imersos em solução aquosa de azul de metileno a $2 \%$, durante setenta e duas horas, a $37^{\circ} \mathrm{C}$. A seguir, os dentes foram seccionados longitudinalmente e a infiltração apical avaliada em um estereomicroscópio. O sistema Microseal apresentou a melhor capacidade de selamento apical, seguido pelo System B, JS Quick-Fill, Ultrafil e pela técnica da condensação lateral. A análise estatística dos resultados demonstrou que: 1. o sistema Microseal apresentou selamento apical semelhante ao do System B e melhor que dos demais grupos; 2. o System B apresentou selamento apical melhor que o da técnica da Condensação Lateral e semelhante ao dos demais grupos; 3. os grupos da Condensação Lateral, Ultrafil e JS Quick-Fill, apresentaram capacidade de selamento semelhante.

UNITERMOS: Obturação do canal radicular; Infiltração dentária.

\section{ACKNOWLEDGEMENTS}

The authors thank FAPESP for financial support.

\section{REFERENCES}

1- Al-Dewani N, Hayes SJ, Dummer PMH. Comparison of laterally condensed and low-temperature thermoplasticized gutta-percha root fillings. J Endod 2000; 26(12): 733-8.

2- Bonetti Filho I, Tagliaferro AC, Tanomaru Filho M, Mendes ADJ. Avaliação "in vitro" da capacidade seladora da técnica de obturação Microseal através da infiltração apical do corante azul de metileno a 2\%. Rev Bras Odontol 2000; 57(2): 80-3.

3- Bramante CM, Berbert A, Piccino AC. Técnica de condensação lateral para obturações de canais radiculares de pequenos diâmetros, com cones de guta-percha. Estomat. Cult. 1972; 6(1): 70-2.

4- Buchanan LS. The continuous wave of obturation technique: "centered" condensation of warm gutta percha in 12 seconds. Dent Today 1996 Jan; 15(1): 60-7.
5- Canalda-Sahli C, Berástegui-Jimeno E, Brau-Aguadé E. Apical sealing using two thermoplasticized gutta-percha techniques compared with lateral condensation. J Endod. 1997; 23(10): 6368.

6- Czonstkowsky M, Michanowicz A, Vazquez JA. Evaluation of an injection of thermoplasticized low-temperature gutta-percha using radioactive isotopes. J Endod. 1985; 11(2): 71-4.

7- Davalou S, Gutmann JL, Nunn MH. Assessment of apical and coronal root canal seals using contemporary endodontic obturation and restorative materials and techniques. Int Endod J 1999 Sept; 32(5): 388-96.

8- Gençoglu N, Samani S, Günday M. Dentinal wall adaptation of thermoplasticized gutta-percha in the absence or presence of smear layer: a scanning electron microscopic study. J Endod. 1993; 19(11): 558-62.

9- Greene HA, Wong M, Ingram TA. Comparison of the sealing ability of four obturation techniques. J Endod 1990; 16(9): 423-8.

10-Gulabivala K, Holt R, Long, B An in vitro comparison of thermoplasticized gutta-percha obturation techniques with cold lateral condensation. Endod Dent Traumatol 1998; 14(6): 262-9.

11- Ingle JI, Bakland LF Endodontics. $4^{\text {th }}$ ed. Philadelphia: Lea \& Febiger; 1994

12- Korzen BH. Endodontic obturation using the Microseal technique. Oral Health 1997 Oct; 87(10): 67-73.

13- Kytridou V, Gutmann JL, Nunn MH. Adaptation and sealability of two contemporary obturation techniques in the absence of the dentinal smear layer. Int Endod J 1999 Nov; 32(6): 464-74.

14- Pallarés A, Faus V. A comparative study of the sealing ability of two root canal obturation techniques. J Endod. 1995 Sept; 21(9); 449-50.

15- Pommel L, Camps J. In vitro apical leakage of System B compared with other filling techniques. J Endod 2001July; 27(7): 449-51.

16- Schilder H. Filling root canals in three dimensions. Dent Clin North Am 1967 Nov; 11: 723-44.

17- Shakespeare RC, Donnelly JC. An in vitro comparison of apical microleakage after obturation with JS Quick-Fill or Lateral Condensation. J Endod 1997, 23(5): 312-4.

18- Weine FS Endodontic therapy. $4^{\text {th }}$ ed. St Louis: Mosby. 1989.

Recebido para publicação em: 10/02/2003

Aceito após reformulações em: 14/03/2003

Endereço: Viviane Haiub Brosco

Al. Octávio Pinheiro Brisolla, $n^{\circ}$ 6-65, ap. 33

Vila Universitária, cep 17043 -100, Bauru- SP

Fone: (14) 2347762

Email: vivi150@uol.com.br 